\title{
PENINGKATAN KREATIVITAS PADA ANAK USIA DINI MELALUI PEMBELAJARAN BERBASIS TIK DI TK TUNAS MEKAR KECAMATAN SUKASADA KABUPATEN BULELENG
}

\author{
I Made Hartawan \\ STAHN MPU Kuturan Singaraja \\ hartawanmade51@gmail,com
}

\begin{abstract}
The learning method currently being developed is the ICT-based learning method. This happens because it is in line with the development of ICT and demands in the world of education for learning to be more advanced, more efficient and effective. So that learning objectives can be achieved properly. This study aims to determine whether ICT-based learning can increase the creativity of early childhood.This research was conducted at TK Tunas Mekar, Sukasada District, Buleleng Regency. This research is a classroom action research and consists of two cycles and each cycle consists of 4 steps, namely Planning (Planning), Action (Action), Observation (Observation), Reflection (Reflection). In this research area determination technique using purposive sampling area. Determination of respondents with Research Population. Data collection was carried out by observation and documentation. Data analysis in this classroom action research used the percentage of learning completeness formula. The results of this study indicate an increase in children's creativity and ICT-based learning. Evidently, the results of the data before using ICTbased learning were only $46.6 \%$ of students who had good creativity abilities then increased to $79.9 \%$ after using ICT-based learning. In this cycle, the child's creativity has increased and meets the $75 \%$ set target.

Keywords: Early childhood creativity, ICT-based learning
\end{abstract}




\begin{tabular}{|c|c|c|}
\hline \multicolumn{3}{|c|}{ Jurnal Warna : Jurnal Pendidikan Dan Pembelajaran Anak Usia dini. } \\
September 2020. Vol 05. No. 02 \\
\hline Received: Agustus 2020 & Accepted: Agustus 2020 & Published: September 2020 \\
\hline & Article DOI: $10.24903 / j w . v 5 i 2.536$ \\
\hline
\end{tabular}

\section{Pendahuluan}

Anak usia dini merupakan masa yang tepat untuk melakukan pendidikan. Pada masa ini, anak sedang mengalami proses pertumbuhan dan perkembangan yang luar biasa. Anak belum memiliki pengaruh negatif yang banyak dari luar atau dari lingkungannya. Dengan kata lain, orang tua mau pun guru akan lebih mudah mengarahkan anak menjadi yang baik dan berkarakter. Dalam UU No. 20 tahu 2003 Pasal 1 butir 14 tentang Sistem Pendidikan Nasional disebutkan bahwa pendidikan anak usia dini adalah suatu upaya pembinaan yang ditujukan kepada anak sejak lahir sampai dengan usia enam tahun, yang dilakukan melalui pemberian rangsangan pendidikan untuk membantu pertumbuhan dan perkembangan jasmani dan rohani, agar anak memiliki kesiapan dalam memasuki pendidikan lebih lanjut.

Pendidikan bagi anak usia dini sangat penting dalam rangka mengembangkan segala potensi atau kemampuan yang dimilikinya. Dalam dunia psikologi, disebutkan bahwa anak usia dini merupakan masa yang cemerlang untuk dilakukan pendidikan.
Mereka menyebutnya dengan istilah Golden Age, yaitu seorang anak mempunyai potensi yang sangat besar untuk berkembang. Pada usia ini 90\% dari fisik otak anak sudah terbentuk (Maimunah Hasan, 2010:30). Hasil kajian neurologi menunjukkan bahwa pada saat lahir otak bayi membawa potensi sekitar 100 milyar yang pada proses berikutnya sel-sel dalam otak tersebut berkembang dengan begitu pesat menghasilkan bertriliun-triliun sambungan antar neuron. Supaya mencapai perkembangan optimal, sambungan harus diperkuat berbagai rangsangan psikososial karena sambungan yang tidak diperkuat akan mengalami penyusutan dan musnah. Apabila anak jarang memperoleh rangsangan pendidikan, perkembangan otaknya lebih kecil 20-30\% dari ukuran normal anak seusianya (Uyu Wahyudin dan Mubiar Agusti, 2011:2).

Istilah pembelajaran berasal dari kata belajar, yaitu suatu aktivitas atau suatu proses untuk memperoleh pengetahuan, meningkatkan keterampilan, memperbaiki perilaku, sikap dan mengukuhkan kepribadian (Suyono dan Hariyanto, 2011:9). Pengertian ini lebih diartikan kepada 


\begin{tabular}{|c|c|c|}
\hline \multicolumn{3}{|c|}{ Jurnal Warna : Jurnal Pendidikan Dan Pembelajaran Anak Usia dini. } \\
September 2020.Vol 05. No. 02 \\
\hline Received: Agustus 2020 & Accepted: Agustus 2020 & Published: September 2020 \\
\hline & Article DOI: 10.24903/jw.v5i2.536 \\
\hline
\end{tabular}

perubahan individu seseorang, baik menyangkut ilmu pengetahuan maupun berkaitan dengan sikap dan kepribadian dalam kehidupan sehari-hari. Melalui pembelajaran ini harapannya ilmu akan bertambah, keterampilan meningkat dan dapat membentuk akhlak mulia. Untuk menciptakan suasana pembelajaran yang menyenangkan, seorang guru diharapkan dapat menjalin interaksi atau hubungan yang baik dan penuh keakraban dengan siswa. Selain itu pembelajaran menyenangkan juga terwujudkan melalui metode mau pun strategi pembelajaran yang mengasyikkan dan menyenangkan. Dimana antara guru dan siswa terlibat secara langsung dalam proses pembelajaran.

Metode pembelajaran pada saat ini yang mulai banyak dikembangkan adalah metode pembelajaran berbasis Teknologi Informasi dan Komunikasi (TIK). Hal ini terjadi karena sejalan dengan perkembangan TIK serta tuntutan dalam dunia pendidikan agar pembelajaran semakin maju, lebih efisien dan efektif. Sehingga tujuan dalam pembelajaran dapat tercapai dengan baik. Mendaya gunakan TIK di lembaga pendidikan adalah salah satu upaya untuk meningkatkan mutu pendidikan di Indonesia.

ICT (Information and Communicatoin Technology)based learning atau pembelajaran berbasis Teknologi Informasi dan Komunikasi (TIK) menggambarkan kecanggihan dalam pembelajaran. Peluang baru yang dijanjikan teknologi ini sangat luas. Kreativitas guru sangat berperan penting, karena tanpa itu teknologi ini tidak akan bermanfaat. Peran TIK dalam pembelajaran hanya sebatas sebagai alat bantu. Guru yang menguasai alat bantu TIK dengan baik akan menghasilkan media pembelajaran yang menjadikan TIK berperan dalam kegiatan pembelajaran.

TIK sebagai solusi pembelajaran pada intinya adalah sebagaimana menyajikan materi pembelajaran secara menarik sehingga anak senang untuk belajar dan bagaimana proses belajar itu tidak dibatasi oleh ruang dan waktu. Dimana saja, kapan saja anak bisa membangun sendiri pengetahuannya. Penyajian materi yang baik bisa menstimulus anak untuk berfikir kritis dan kreatif, mengembangkan pengetahuannya dan mengaplikasikan pengetahuannya secara konkret. Karena 


\begin{tabular}{|l|c|c|}
\hline \multicolumn{3}{|c|}{ Jurnal Warna : Jurnal Pendidikan Dan Pembelajaran Anak Usia dini. } \\
September 2020.Vol 05. No. 02 \\
\hline Received: Agustus 2020 & Accepted: Agustus 2020 & Published: September 2020 \\
\hline & Article DOI: $10.24903 / j w . v 5 i 2.536$ \\
\hline
\end{tabular}

dengan pemahaman yang menyeluruh tentang suatu konsep pengetahuan, tidak hanya akan membuat daya ingat anak semakin kuat tetapi kemampuan anak untuk problem solving juga akan semakin terasah.

Hasil pengamatan pembelajaran di TK Tunas Mekar Kecamatan Sukasada Kabupaten Buleleng masih menggunakan pembelajaran tradisional dan konvensional,anak mengamati gambar lalu mengungkapkan imajinasinya. Hal ini terlihat ketika pembelajaran setiap hari anak mengamati gambar sesuai tema lalu menceritakan apa yang ada difikirannnya.

Kegiatan kreativitas anak di TK Tunas Mekar Kecamatan Sukasada Kabupaten Buleleng dilembaga menggunakan kegiatan kolase, menggambar, dan mewarnai. Sehingga kegiatan tersebut monoton kurang menarik untuk anak. Agar mencapai peningkatan kemampuan kreativitas anak di TK Tunas Mekar Kecamatan Sukasada Kabupaten Buleleng, peneliti berusaha semaksimal mungkin dengan cara lain menggunakan pembelajaran yang tepat, karena sifat anak yang mudah bosan maka dalam melaksanakan pembelajaran, peneliti menggunakan pembelajaran berbasis TIK agar anak tertarik dan mempunyai daya imajinasi yang lebih lagi.

Oleh karena itu, peneliti melakukan tindakan kelas dengan judul "Peningkatan Perkembangan Kreativitas Pada Anak Usia Dini Melalui Pembelajaran Berbasis Teknologi Informasi Dan Komunikasi Di TK Tunas Mekar Kecamatan Sukasada Kabupaten Buleleng”.

\section{METODE}

Peneliti disini menggunakan PTK (Penelitian Tindakan Kelas) disebut dengan Classroom Actoin Research. Menurut Suharsimi (2012:5) mendefinisikan Penelitian Tindakan Kelas melalui paparan gabungan definisi dari kata "penelitian", "tindakan" dan "kelas". Jadi Suharsimi (2012:5) berkesimpulan PTK adalah suatu pencermatan terhadap kegiatan belajar berupa sebuah tindakan, yag sengaja dimunculkan dan terjadi dalam sebuah kelas secara bersama. Tindakan tersebut diberikan oleh guru atau dengan arahan dari guru yang dilakukan oleh siswa.

$$
\text { Suhardjono }
$$
mendefinisikan PTK adalah penelitian 


\begin{tabular}{|c|c|c|}
\hline \multicolumn{3}{|c|}{ Jurnal Warna : Jurnal Pendidikan Dan Pembelajaran Anak Usia dini. } \\
September 2020. Vol 05. No. 02 \\
\hline Received: Agustus 2020 & Accepted: Agustus 2020 & Published: September 2020 \\
\hline & Article DOI: $10.24903 / j w . v 5 i 2.536$ \\
\hline
\end{tabular}

tindakan yang dilakukan dikelas dengan tujuan memperbaiki/meningkatkan mutu praktik pembelajaran. Tujuan PTK menurut Suhardjono (2012:13) sebagai berikut:

a. Meningkatkan mutu isi, masukkan, proses, serta hasil pendidikan dan pembelajaran disekolah.

b. Membantu guru dan tenaga kependidikan lainnya mengatasi masalah pembelajaran dan pendidikan didalam kelas.

c. Meningkatkan sikap professional pendidik dan tenaga kependidikan.

d. Menumbuh kembangkan budaya akademik dilingkungan sekolah sehingga tercipta sikap proaktif didalam melakukan perbaikan mutu pendidikan dan pembelajaran secar berkelanjutan.

Secara ringkas pada dasarnya PTK memiliki manfaat sebagai berikut:

a. Membantu guru memperbaiki kualitas pemeblajarannya.

b. meningkatkan profesionalitas guru.

c. Meningkatkan rasa percaya diri guru.

d. memungkinkan guru secara aktif mengembangkan pengetahuan dan ketrampilan.
Agar penelitian tindakan kelas dapat terlaksana dengan baik, ada sejumlah kondisi tertentu perlu diperhatikan, yaitu:

a. Kesediaan guru untuk mengakui kekurangan atau kelemahan diri berkaitan dengan kegiatan pembelajaran yang selama ini dilakukan

b. Kesempatan yang memadai bagi guru untuk menemukan dan mengembangkan sesuatu yang baru.

c. Dorongan yang kuat dari dirinya sendiri untuk memgembangkan gagasan-gagasan baru berkenaan dengan kegiatan pembelajaran

d. Waktu yang tersedia secara memadai dan keseriusan untuk mengelola waktu tersebut Antara kegiatan rutin yang sekaligus juga melakukan penelitian tindakan kelas untuk mencoba tindakantindakan yang baru.

e. Berkembangnya kepercayaan timbal balik antara guru, siswa, teman sejawat, dan kepala sekolah.

Rancangan Penelitian yang digunakan adalah salah satu strategi penyelesaian masalah yang memanfaatkan tindakan nyata dan 


\begin{tabular}{|c|c|c|}
\hline \multicolumn{3}{|c|}{ Jurnal Warna : Jurnal Pendidikan Dan Pembelajaran Anak Usia dini. } \\
September 2020.Vol 05. No. 02 \\
\hline Received: Agustus 2020 & Accepted: Agustus 2020 & Published: September 2020 \\
\hline & Article DOI: 10.24903/jw.v5i2.536 \\
\hline
\end{tabular}

proses pengembangan kemampan dalam mendeteksi dan menyelesaikan masalah. Dalam prosesnya, pihak-pihak yang terlibat saling mendukung satu sama lain dengan melengkapi faktafakta dan mengembangkan kemampuan analisis.

Chotimah (dalam Mahmubah 2015:19) menerangkan bahwa dalam praktek penilitian tindakan kelas menggabungkan tindakan bermakna dengan prosedur penelitian. Hal ini merupakan suatu upaya meyelesaikan masalah sekaligus mencari dukungan ilmiahnya. Secara sadar pihak yang terlibat (calon guru, dosen, instrktur, kepala sekolah dan warga sekolah) mencoba merumuskan suatu tindakan atau intervensi yang diperhitungkan dapat menyelesaikan masalah atau memperbaiki situasi dan diperkirakan secara cermat mengamati pelaksanaannya untuk memahami tingkat keberhasilannya.

\section{HASIL DAN PEMBAHASAN}

Penelitian tindakan ini menggunakan Penelitian Tindakan Kelas (PTK). PTK ini terdiri 4 tahap, yaitu: 1. Perencanaa (Planning), 2. Tindakan (Action), 3. Pengamatan (Observation), 4. Refleksi (Reflection).
Adapun proses pelaksanaan dalam penelitian pada siklus satu adalah sebagai berikut:

\section{Perencanaan (Planning)}

Pada tahap ini peneliti menyusun rencana pembelajaran berdasarkan pokok bahasan dengan Tema Tanaman dan Sub Tema Bunga, kemudian menyusun langkah-langkah pembelajaran, merencanakan bagaimana cara dan aturan-aturan yang akan disampaikan pada anak didik, menyiapkan media yang dubutuhkan yang dengan kreativitas misalnya mewarnai gambar bunga.

\section{Tindakan (Action)}

Dalam melaksanakan pengajaran peneliti melakukan tindakkan membutuhkan waktu 1 minggu untuk siklus satu yang memacu pada kreativitas anak dalam mewarnai memakai chrayon, langkah-langkah yang dilakukan adalah sebagai berikut:

a. Mengawali kegiatan belajar, guru mengajak siswa berdo'a terlebih dahulu dan menyanyikan lagu "Lihat Kebunku"

b. Guru bercakap-cakap tentang macam-macam bunga 


\begin{tabular}{|c|c|c|}
\hline \multicolumn{3}{|c|}{ Jurnal Warna : Jurnal Pendidikan Dan Pembelajaran Anak Usia dini. } \\
September 2020.Vol 05. No. 02 \\
\hline Received: Agustus 2020 & Accepted: Agustus 2020 & Published: September 2020 \\
\hline & Article DOI: $10.24903 /$ jw.v5i2.536 \\
\hline
\end{tabular}

c. Guru menjelaskan macam-macam tanaman bunga

d. Guru menjelaskan langkahlangkah kegiatan yang akan dilakukan

e. Guru menunjuk anak untuk duduk didepan kompur, 1 komputer 2 anak

f. Anak dipersilahkan untuk mewarnai gambar yang sudah disediakan di Microsoft Paint

g. Apabila selesai anak disuruh duduk kembali ditempat semula

2. Pengamatan (Observation)

Setelah anak selesai mengerjakan tugas yang diberikan, peneliti bersama guru pemdamping melakukan observasi dan mencatat bagaimana kreativitas anak melalui kegiatan mewarnai bunga menggunakan Microsoft Paint, sehingga terlihat apakah anak mampu menyalurkan imajinasinya melalui kegiatan tersebut.

\section{Refleksi (Reflection)}

Dari hasil obsevasi, dilakukan analisis kemudian dilanjutkan dengan refleksi untuk mengkaji semua hal yang terjadi. Jika hasil perhitungan dan analisis pada pada siklus satu menunjukkan bahwa kemampuan kreativitas anak belum mencapai 70\%, maka rencana selanjutnya adalah menuyusun rencana perbaikan yang digunakan guru untuk memperbaiki kemampuan kreativitas anak dengan melanjutkan pada siklus dua dan siklus selanjutnya.

Dari hasil observasi dapat dikumpulkan sejumlah data yang berhubungan dengan Kreativitas anak di TK Tunas Mekar Kecamatan Sukasada Kabupaten Buleleng.

Berdasarkan hasil penelitian mengenai kreativitas anak melalui mewarnai gambar bunga menggunakan chrayon pada siklus satu dari kategori baik diperoleh nilai $46,6 \%$ dari seluruh siswa. Kemampuan siswa menunjukkan bahwa kreativitas anak melalui mewarnai bunga menggunakan Microsoft Paint belum mencapai $75 \%$ dari keseluruhan jumlah siswa sehinga perlu diadakan siklus dua.

Tahapan yang dilakukan pada siklus dua yaitu sebagai berikut:

1. Perencanaan (Planning)

Pada tahap ini peneliti menyusun rencana pembelajaran berdasarkan pokok bahasan dengan tema Tanaman 


\begin{tabular}{|c|c|c|}
\hline \multicolumn{3}{|c|}{ Jurnal Warna : Jurnal Pendidikan Dan Pembelajaran Anak Usia dini. } \\
September 2020. Vol 05. No. 02 \\
\hline Received: Agustus 2020 & Accepted: Agustus 2020 & Published: September 2020 \\
\hline \multicolumn{3}{|c|}{ Article DOI: $10.24903 /$ jw.v5i2.536 } \\
\hline
\end{tabular}

dan Sub tema Bunga, kemudian menyusun

langkah-langkah

pembelajaran, rencana pembelajaran, merencanakan bagaimana cara dan aturan-aturan yang akan disampaikan pada anak didik, menyiapkan media Pembelajaran berbasis TIK yang berhubungan kreativitas anak.

2. Tindakan (Action)

Melakukan pengajaran pada siklus dua ini peneliti membutuhkan waktu 1 minggu yang mengacu pada kreativitas anak dalam pembelajaran berbasis TIK, langkah-langkah yang dilakukan adalah sebagai berikut:

a. Mengawali kegiatan belajar, guru mengajak siswa berdo'a terlebih dahulu dan menyanyikan "Lihat Kebunku”.

b. Guru bercakap-cakap mengulang pelajaran hari kemaren dan mulai menjelaskan tema pelajaran yang akan dipelajari hari ini.

c. Guru menjelaskan tentang makhluk cipataan Tuhan, misal manusia, hewan, dan tumbuhan.

d. Guru menjelaskan macam-macam tanaman bunga.

e. Guru menyiapkan computer yer yang digunakan dalam kegiatan ini. f. Guru menjelaskan terlebih dahulu kegiatan yang akan dilakukan

g. Guru menunjukkan 4 anak untuk maju dan mengambil posisi didepan komputer

h. Guru mempersilahkan anak untuk mewarnai gambar yang sudah disediakan di Ms Paint pada komputer setiap anak.

i. Apa bila anak selesai, anak dipersilahkan duduk ditempat semula.

3. Pengamatan (Observation)

Setelah anak selesai mengerjakan tugas yang diberikan, peneliti melakukan observasi dan mencatat bagaimana Kreativitas anak dalam kegiatan mewarnai melalui pembelajaran berbasis TIK.

4. Refleksi (reflection)

Berdasarkan hasil observasi, dilakukan analisis kemudian dilanjutkan dengan refleksi untuk mengkaji semua hal yang terjadi. Pada siklus dua ini refleksi yang dilakukan yaitu menempatkan anak ditempat yang lebih nyaman misalnya, tidak lerlalu banyak suara atau ramai, tidak lembab dan banyak nyamuk. Jika hasil perhitungan dan analisis pada siklus satu menunjukkan bahwa kemampuan 


\begin{tabular}{|c|c|c|}
\hline \multicolumn{3}{|c|}{ Jurnal Warna : Jurnal Pendidikan Dan Pembelajaran Anak Usia dini. } \\
September 2020.Vol 05. No. 02 \\
\hline Received: Agustus 2020 & Accepted: Agustus 2020 & Published: September 2020 \\
\hline & Article DOI: 10.24903/jw.v5i2.536 \\
\hline
\end{tabular}

kreativitas anak belum mencapai 75\% maka rencana selanjutnya adalah menyusun rencana perbaikan yang digunakan guru untuk memperbaiki kemampuan kreativitas anak dengan melanjutkkan pada siklus dua dan siklus selanjutnya.

Setelah diadakan refleksi maka langkah selanjutnya yaitu menyusun rencana perbaikan pembelajaran yang digunakan peneliti untuk meningkatkan kemampuan kreativitas anak. Pelaksanaan kegiatan belajar mengajar untuk siklus dua TK Tunas Mekar Kecamatan Sukasada Kabupaten Buleleng.

adapun proses belajar mengajar mengacu pada scenario pembelajaran yang tercantum pada rencana harian (RKH)

Hasil observasi siklus satu dari 15 siswa terdapat 1 siswa yang dikategorikan kurang dengan skor 1 dimana anak masih belum mau melakukan kegiatan sama sekali. Siswa yang dikategorikan cukup sebanyak 7 siswa dengan skor 2 dimana anak melakukan kegiatan masih dengan bantuan guru. Pada kategori baik dengan nilai skor 3 dimana anak mampu melakukan kegiatan mewarnai maskipun keluar garis sebanyak 7 siswa.

Pemaparan diatas, presentase yang diperoleh dari kreativitas anak usia dini dalam pembelajaran berbasis TIK yang dikategorikan baik sebesar 46,6\%. Angka 46,6\% masih jauh dari pencapaian indicator kinerja sebesar $75 \%$. Hal ini sesuai dengan pendapat Abdussalam yang menyatakan bahwa lukisan termasuk sarana edukatif utama paling penting untuk mengembangkan kreativitas. Lukisan merupana salah satu cara mengembangkan bakat, inovasi dan kreativitas, serta salah satu bidang terpenting dalam merealisasikan diri kreatif dan bakat seni para murid secara umum, dan bakat seni anakanak TK secara khusus. Dengan Microsoft Pain anak dapat menggambar apa saja yang ia inginkan, seperti menggambar apa saja yang ia inginkan.

Langkah pada siklus dua sama seperti langkah yang dilakukan pada siklus satu seperti perencanaan (Planning), tindakan (Action), pengamatan (Observation), dan refleksi (Reflection). Setelah diadakan refleksi maka langkah selanjutnya 


\begin{tabular}{|l|c|c|}
\hline \multicolumn{3}{|c|}{ Jurnal Warna : Jurnal Pendidikan Dan Pembelajaran Anak Usia dini. } \\
September 2020.Vol 05. No. 02 \\
\hline Received: Agustus 2020 & Accepted: Agustus 2020 & Published: September 2020 \\
\hline & Article DOI: $10.24903 / j w . v 5 i 2.536$ \\
\hline
\end{tabular}

yaitu menyusun rencana perbaikan pembelajaran yang digunakan untuk meningkatkan kreativitas anak. Langkah perbaikan yaitu menggunakan media pembelajaran berbasis TIK.

Berasarkan observasi yang dilakukan selama proses pembelajaran pada siklus II, diketahui bahwa dari 15 siswa 1 anak dikategorikan kurang yaitu dengan skor 1 yang berarti anak tidak mau melakukan kegiatan sama sekali. Siswa yang dikategorikan cukup sebanyak 2 siswa dengan skor 2 dimana anak melakukan kegiatan meskipun dengan bantuan guru. Pada kategori baik dengan skor 3 dimana anak mampu mewarnai meskipun masih keluar garis sebanyak 5 siswa. Untuk kategori baik sekali terdapat 7 siswa dengan skor 4 dimana anak mampu mewarnai dengan penuh.

Terlihat dari pemaparan diatas dapat diketahui persentase kreativitas anak usia melalui kegiatan mewarnai dari kategori baik dan baik sekali sebesar 79.9\%. Hasil yang didapat merupakan pengaruh menggunakan pembelajaran berbasis TIK terbukti anak lebih mampu mengembangkan dan menyalurkan imajinasinya.
Penelitian tindakan kelas pada siklus dua kerana angka yang diperoleh telah mencapai indikator kerja sebesar $75 \%$.

Peningkatan kreativitas anak setelah menggunakan pembelajaran berbasis TIK pada kategori baik meningkat $33,3 \%$ dari yang sebelumnya $46,6 \%$ menjadi $79,9 \%$. Berdasarkan data yang diperoleh melalui observasi disimpulkan bahwa pembelajaran berbasis TIK dapat meningkatkan kreativitas anak di TK Tunas Mekar Kecamatan Sukasada Kabupaten Buleleng.

\section{PENUTUP}

Kesimpulan

Berdasarkan hasil penelitian, maka dapat ditarik kesimpulan bahwa dalam menggunakan media pembelajaran berbasis TIK terbukti ada pengaruh terhadap kreativitas anak di TK Tunas Mekar Kecamatan Sukasada Kabupaten Buleleng. Hal tersebut ditandai dengan ketercapaian indikator keberhasilan penelitian tindakan kelas sebesar 79,9\%. Hasil penelitaian mengenai kreativitas di siklus satu dari kategori baik diperoleh nilai 46,6\% dari seluruh siswa. Kemampuan siswa menujukkan bahwa kreativitas anak belum mencapa indikator kerja 75\% 


\begin{tabular}{|l|c|c|}
\hline \multicolumn{3}{|c|}{ Jurnal Warna : Jurnal Pendidikan Dan Pembelajaran Anak Usia dini. } \\
September 2020.Vol 05. No. 02 \\
\hline Received: Agustus 2020 & Accepted: Agustus 2020 & Published: September 2020 \\
\hline & Article DOI: $10.24903 / j w . v 5 i 2.536$ \\
\hline
\end{tabular}

dari keseluruhan jumlah siswa sehingga perlu diadakan siklus dua.

Pada uraian diatas dari siklus dua dapat diketahui adanya peningkatan kreativiatas anak dibandingkan dengan hasil siklus satu sebesar $46,6 \%$ menjadi $79,9 \%$. Pada siklus ini kreativitas anak sudah mengalami peningkatan dan memenuhi target yang telah ditetapkan $75 \%$.

Saat kegiatan belajar mengajar menggunakan pembelajaran berbasis TIK, aktifitas siswa dalam mengikuti pembelajaran juga terlihat semakin meningkat dari rata-rata cukup dan kurang menjadi baik bahkan baik sekali. Demikian juga aktivitas guru semakin meningkat yakni mampu mengelola proses pembelajaran lebih efektif, inovatif, kreatif, dan menyenangkan.

Saran

Saran yang dibuat berdasarakan kesimpulan diatas sebagai berikut:

1. Guru hendaknya lebih memiliki komitmen yang tinggi dalam menjalankan tugasnya dengan menjalankan tugas pokok secara professional, mengkaji dan menerapkan berbagai inovasi pembelajaran secara variatif untuk upaya meningkatkan kreativitas.

2. Kepala sekolah dan pengawas sekolah hendaknya lebih mengintensifikasikan perannya sebagai supervisor agar guru memiliki motivasi dalam menerapkan media pembelajaran yang lebih bermakna. Selebihnya pemberian kesempatan untuk mengikuti workshop, penataran, bimtek, dan sebagainya.

\section{DAFTAR PUSTAKA}

Abdy. 2011. Pendidikan ICT Pada Anak UsiaDini.http://abdiplizz.wordpress.co $\mathrm{m} / 2011 / 01 / 11$ /pendidikan-ict-padaanak-usia-dini-2/. Diakses pada tanggal 27 Maret 2020

Ali, M \& Asrori, M. 2005. Psikologi Remaja, Perkembangan Siswa. Jakarta: Bumi Aksara

Aprilia. 2012. Teknologi Informasi dan Komunikasi.http://pgpaudduaa.wordspr ess.com/2012/06/20/teknologiinformasi-dan-komunikasi/._Diakses pada tanggal 28 Maret 2020

Fadillah, Muhammad. 2012. Desain Pembelajaran PAUD, Tinjauan Teoritik dan Praktik. Jogjakarta: Ar-Ruzz Media

Fatimah, Enung. 2006. Psikologi Perkembangan: Perkembangan Siswa. Bandung: Pustaka Setia

Hasan, Maimunah. 2010. Pendidikan Anak Usia Dini. Jogjakarta: Diva Press

Hurlock, Elizabeth, B. 1978. Perkembangan Anak. Jakarta: Erlangga

Inggridwati Kurnia, dkk. 2007. Bahan Ajar Cetak; Perkembangan Belajar Siswa. Direktorat Jenderal Pendidikan Tinggi Departemen Pendidikan Nasional. 
Jurnal Warna : Jurnal Pendidikan Dan Pembelajaran Anak Usia dini. September 2020. Vol 05. No. 02

Received: Agustus 2020 $\quad$ Accepted: Agustus 2020 Article DOI: 10.24903/jw.v5i2.536

Munandar, S. C. U. 1999. Kreativitas dan Keterbakatan; Strategi Mewujudkan Potensi Kreatif dan Bakat. Jakarta: Gramedia Pustaka Umum

Munawaroh, Jazilatul. 2014. Pengaruh Metode Plastisin Terhadap Kreativitas Anak di TK PGRI. Jember

Munir. M.IT. 2009. Pembelajaran Jarak Jauh Berbasis Teknologi Informasi dan Komunikasi. Bandung: Alfabeta

Setyo. 2010. Pembelajaran Berbasis TIK Pada Anak Usia Dini.http://setyo155.wordpress.com/20 10/12/17/pembelajaran-berbasis-tikpada-anak-usia-dini-sebagai-generasiberkarakter/.Diakses pada tanggal 28 Maret 2020

Sumiharsono. Rudy. 2009. Metodologi Penelitian. Jember. IKIP PGRI

Suyono dan Hariyanto. 2011. Belajar dan Pembelajaran; Teori dan Konsep Dasar. Bandung: Remaja Rosdakrya

Undang-undang Republik Indonesia Nomor 20 tahun 2003 tentang Sistem Pendidikan Nasional

Wahyudin, Uyu dan Mubiar Agustin. 2011. Penilaian Perkembangan Anak Usia Dini. Bandung: Refika Aditama 